\title{
TERRAS INDÍGENAS COMO CATEGORIA CORRELATA AO CONCEITO DE TERRITÓRIO
}

Ib Sales Tapajós ${ }^{1}$

RESUMO: Este artigo propõe uma reflexão sobre o conceito de terras indígenas, inscrito no artigo 231 da Constituição Federal de 1988, e sua correlação com o conceito contemporâneo de território, formulado no âmbito da Geografia e da Antropologia. A partir de uma abordagem interdisciplinar acerca da legislação indigenista vigente no Brasil, o artigo propõe uma interpretação da categoria terras indígenas como correlata ao conceito de territórios sociais, dotados de uma autonomia que precisa ser respeitada pelo Estado e pela sociedade.

Palavras-chave: Constituição; terras indígenas; território; autonomia; povos indígenas.

\section{INDIGENOUS LANDS AS A CATEGORY CORRELATED TO THE CONCEPT OF TERRITORY}

\begin{abstract}
This article proposes a reflection on the concept of indigenous lands, inscribed in article 231 of the Federal Constitution of 1988, and its correlation with the contemporary concept of territory formulated in the scope of Geography and Anthropology. Based on an interdisciplinary approach on the indigenous legislation in force in Brazil, the article proposes an interpretation of the category indigenous lands as correlated to the concept of social territories, endowed with an autonomy that must be respected by the State and by society.
\end{abstract}

Key-words: Constitution; indigenous lands; territory; autonomy; indigenous people.

\section{INTRODUÇÃO}

Desde a Constituição Federal de 1934, os direitos territoriais indígenas possuem estatura constitucional no Brasil, sendo atribuído ao Estado o dever de proteger as terras indígenas, para permitir a reprodução sociocultural dos índios. Essa missão constitucional foi fortalecida com a Carta de 1988, que adotou o paradigma de um Estado pluriétnico e

\footnotetext{
${ }^{1}$ Advogado militante. Graduado em Direito pela Universidade Federal do Pará. Especialista em Direito Público pela Universidade Anhanguera/Uniderp. Mestrando em Ciências da Sociedade na Universidade Federal do Oeste do Pará. E-mail: ibtapajos@hotmail.com.
} 
multicultural (DUPRAT, 2006). Com a “Constituição Cidadã”, houve um reforço substancial na proteção jurídica dos direitos territoriais indígenas.

Não obstante, mesmo com o avanço no plano do direito positivo, nota-se a persistência, no conjunto das instituições estatais, destacadamente no Poder Judiciário, de uma forte incompreensão sobre a natureza da categoria terras indígenas e suas repercussões jurídicas, o que enseja decisões extremamente problemáticas que acabam neutralizando os direitos territoriais previstos na Carta Magna.

Essa incompreensão fica evidente quando os membros do Judiciário afirmam solenemente que as terras indígenas não são territórios, afirmação que costuma ser feira em decisões que limitam a autonomia dos povos indígenas na sua relação com a terra e os recursos naturais. Caso emblemático, nesse sentido, foi o julgamento da Petição 3388/RR, envolvendo a Terra Indígena Raposa Serra do Sol, no qual o Supremo Tribunal Federal (STF) impôs um conjunto de 19 condicionantes à demarcação de terras indígenas que limitam drasticamente a autonomia territorial dos povos indígenas (STF, 2009).

Dada essa problemática, o presente artigo propõe uma reflexão sobre o conceito de terra indígena, inscrito no artigo 231 da Constituição de 1988, e sua correlação com o conceito contemporâneo de território, formulado no âmbito da Geografia e da Antropologia. O artigo é fruto de pesquisa bibliográfica e documental, e, a partir de uma abordagem interdisciplinar, propõe uma interpretação da categoria terras indígenas como correlata do conceito de territórios sociais, dotados de uma autonomia que precisa ser respeitada pelo Estado e pela sociedade.

\section{AS TERRAS INDÍGENAS NO DIREITO BRASILEIRO}

Os direitos territoriais indígenas e sua regulamentação jurídica são assuntos de longa data no Brasil. Em esforço de investigação histórica, Cavalcante (2016) identifica o Alvará Régio de $1^{\circ}$ de abril de 1680 , da coroa portuguesa, como o primeiro documento governamental a assegurar alguns direitos aos povos indígenas com relação às suas terras. Após a independência do Brasil, a Lei de Terras de 1850 possibilitou ao Estado reservar terras devolutas para a “colonização dos indígenas” (BRASIL, 1850).

A primeira constituição a assegurar expressamente direitos territoriais aos povos indígenas foi a de 1934, em seu art. 129: "Será respeitada a posse de terras de silvícolas que nelas se achem permanentemente localizados, sendo-lhes, no entanto, vedado aliená-las” 
(BRASIL, 1934). Desde então, todas as constituições brasileiras dedicam algumas linhas às terras indígenas (CF/1937, CF/1946, CF/1967 e EC No 1/69, bem como a CF/88).

A Constituição Federal de 1988 foi, no entanto, uma carta constitucional inovadora nesse assunto, pois, por um lado, alterou o paradigma de relacionamento do Estado com os povos indígenas, e, por outro, incorporou novos princípios e regras no tratamento jurídico das terras indígenas. Considerando os objetivos e limites deste artigo, a discussão sobre o conceito jurídico de terra indígena (e sua correlação com o conceito de território) será feita com base no paradigma constitucional instaurado em 1988.

No texto constitucional de 1988, o artigo 231 e seus parágrafos tratam das terras indígenas nos seguintes termos:

Artigo 231. São reconhecidos aos índios sua organização social, costumes, línguas, crenças e tradições, e os direitos originários sobre as terras que tradicionalmente ocupam, competindo à União demarcá-las, proteger e fazer respeitar todos os seus bens.

$\S 1^{\circ}$ São terras tradicionalmente ocupadas pelos índios as por eles habitadas em caráter permanente, as utilizadas para suas atividades produtivas, as imprescindíveis à preservação dos recursos ambientais necessários a seu bem-estar e as necessárias a sua reprodução física e cultural, segundo seus usos, costumes e tradições. (Grifo nosso).

$\S 2^{\circ}$ As terras tradicionalmente ocupadas pelos índios destinam-se a sua posse permanente, cabendo-lhes o usufruto exclusivo das riquezas do solo, dos rios e dos lagos nelas existentes. (BRASIL, 1988)

O artigo 231 da Constituição de $1988^{2}$ foi resultado de uma ampla mobilização dos povos indígenas brasileiros e seus aliados, que conseguiram exercer forte pressão sobre os deputados constituintes, culminando com a constitucionalização de importantes avanços no campo dos direitos territoriais.

Em verdade, a Carta Constitucional de 1988 funda, no plano jurídico-positivo, um novo tipo de relação entre o Estado brasileiro e os povos indígenas, marcado não mais pelo assimilacionismo autoritário que tenta converter os índios em cidadãos indiferenciados. O jurista Carlos F. Marés Souza Filho (2012) assinala que toda a legislação indigenista brasileira, desde a invasão portuguesa até a Constituição de 1988, foi voltada para a assimilação cultural, isto é, a tentativa de eliminar a existência dos povos indígenas como grupos socialmente

\footnotetext{
${ }^{2}$ Embora não analisado neste artigo, o artigo 232 da Constituição também tem acentuada relevância, por assegurar aos povos indígenas a capacidade processual plena, que os permite defender de forma autônoma todos os seus direitos: "Os índios, suas comunidades e organizações são partes legítimas para ingressar em juízo em defesa de seus direitos e interesses, intervindo o Ministério Público em todos os atos do processo” (BRASIL, 1988).
} 
diferenciados, incorporando-os à comunhão nacional - objetivo que está explícito até mesmo no Estatuto do Índio de $1973 .^{3}$

Segundo o mencionado autor, “A Constituição democrática de 1988 revolucionou a relação entre o Estado e os povos indígenas porque reconheceu o direito de permanecerem para sempre como índios; parecia ser o fim de cinco séculos de política integracionista” (SOUZA FILHO, 2012, p. 90). É preciso salientar, no entanto, que a atuação concreta do Estado brasileiro nem sempre está em sintonia com as leis editadas por ele próprio - situação que é evidente em relação aos direitos indígenas.

Não obstante, é preciso reconhecer que a proteção jurídica dos direitos indígenas avançou de forma substancial com a Constituição de 1988, de modo que Souza Filho destaca principalmente os seguintes avanços:

reconhecer os seus direitos originários, isto é, reconhecer que os povos indígenas têm direitos anteriores ao Direito e aos Estados; reconhecer a exclusividade de seu uso sobre as terras que habitam, nisto incluído o entendimento de que delas dispõem como território e não como propriedade; e, por último, oferecer proteção e garantia do Estado nacional para que os povos indígenas vivam segundo seus direitos originários e não sejam usurpados pelo próprio Estado que os protege, por outros Estados ou por cidadãos de qualquer Estado. (SOUZA FILHO, 2012, p. 91).

O constitucionalista José Afonso da Silva, embora assinale que a Constituição de 1988 não alcançou um nível de proteção inteiramente satisfatório, destaca o avanço que significa a previsão do direito à terra dos índios como direito originário, consagrando uma "relação jurídica fundada no instituto do indigenato, como fonte primária e congênita da posse territorial” (AFONSO DA SILVA, 2008, p. 856).

A tese do indigenato foi criada por juristas brasileiros no período da Lei de Terras de 1850 e consiste na definição dos direitos territoriais indígenas como um direito congênito, anterior a todos os outros, que não é criado pelo Estado, mas sim reconhecido por ele. Como assinala Manuela Carneiro da Cunha (1992, p. 141-142), “o título dos índios sobre suas terras é um título originário, que decorre do simples fato de serem índios: esse título do indigenato, o mais fundamental de todos, não exige legitimação”. Apesar de se tratar de um conceito

\footnotetext{
${ }^{3} \mathrm{O}$ artigo $1^{\circ}$ do Estatuto do Índio afirma que: "Esta Lei regula a situação jurídica dos índios ou silvícolas e das comunidades indígenas, com o propósito de preservar a sua cultura e integrá-los, progressiva e harmoniosamente, à comunhão nacional” ' [grifo nosso] (BRASIL, 1973).
} 
formulado há muito tempo, a Constituição de 1988 foi a primeira a adotar expressamente o termo “originário” para se referir ao direito dos índios sobre suas terras.

Sendo tratado como um direito originário, o conceito jurídico de terra indígena revela um caráter singular. Afinal, segundo a tradição liberal e juspositivista sobre a qual o Estado brasileiro foi edificado, quem cria os direitos e deveres é sempre o Estado. No entanto, esse mesmo Estado reconheceu aos povos indígenas um direito originário sobre as terras que ocupam, ou seja, um direito que precede a existência do Estado.

Por outro lado, o parágrafo $1^{\circ}$ do artigo 231 da Constituição, ao definir o que são as “terras tradicionalmente ocupadas pelos índios”, revela um caráter amplo dessa categoria jurídica. Rompeu-se com a ideia etnocêntrica de que terras indígenas seriam apenas as usadas para moradia e produção agrícola. O conceito se alargou: terras indígenas são aquelas habitadas pelos índios em caráter permanente, as utilizadas para as atividades produtivas, as imprescindíveis à preservação dos recursos ambientais e as necessárias à sua reprodução física e cultural, segundo seus usos, costumes e tradições (BRASIL, 1988).

Na primeira década do século XXI, a proteção constitucional das terras indígenas foi reforçada com a incorporação pelo direito brasileiro de dois importantes documentos internacionais: a Convenção $n^{0} 169$ da Organização Internacional do Trabalho (OIT) e a Declaração das Nações Indígenas sobre os Direitos dos Povos Indígenas.

Apesar de aprovada pela OIT em 1989, a Convenção 169 foi incorporada pelo Estado brasileiro somente no ano de 2004, através do Decreto Legislativo $n^{\circ}$ 5.051, de 19/04/2004. Deve-se destacar que, sendo um tratado internacional sobre direitos humanos, a Convenção 169 da OIT possui status de supralegalidade, isto é, está abaixo da Constituição, porém acima da legislação interna, conforme entende a jurisprudência do Supremo Tribunal Federal ${ }^{4}$.

A Convenção 169 da OIT rompeu com a lógica do desenvolvimento unilinear, própria das políticas integracionistas, que define uma linha evolutiva entre os diversos povos e suas culturas, impondo aos povos “menos evoluídos” um modelo de desenvolvimento que não atende às suas necessidades. A Convenção 169 reconheceu aos povos indígenas o direito à autodeterminação no que se refere à definição de suas prioridades de desenvolvimento, exigindo do Estado respeito ao modo de vida definido por cada povo.

\footnotetext{
4“(...) o caráter especial desses diplomas internacionais sobre direitos humanos lhes reserva lugar específico no ordenamento jurídico, estando abaixo da Constituição, porém acima da legislação interna. O status normativo supralegal dos tratados internacionais de direitos humanos subscritos pelo Brasil, dessa forma, torna inaplicável a legislação infraconstitucional com ele conflitante, seja ela anterior ou posterior ao ato de ratificação". (RE. 466.343-1 São Paulo. Rel. Min. Cezar Peluso. Voto Vogal Ministro. Gilmar Mendes).
} 
Dentro desse escopo, a Convenção dedica sete artigos para tratar das terras dos povos indígenas e tribais (artigo 13 ao 19), onde se lê que “os governos deverão respeitar a importância especial que para as culturas e valores espirituais dos povos interessados possui a sua relação com as terras ou territórios” (BRASIL, 2004). Em tais dispositivos, há várias determinações para que os Estados respeitem e protejam os direitos territoriais indígenas, visando garantir a reprodução sociocultural desses povos diante dos setores majoritários das sociedades nacionais.

A Declaração das Nações Unidas sobre o Direito dos Povos Indígenas, por sua vez, aprovada no ano de 2007, pauta-se pelo mesmo ideário da Convenção 169 da OIT, embora não possua o mesmo status jurídico desta ${ }^{5}$ : o reconhecimento aos povos indígenas do seu direito à diferença, nos marcos da plurietnicidade. Sobre as terras indígenas, interessa mencionar o artigo 26:

\section{Artigo 26}

1. Os povos indígenas têm direito às terras, territórios e recursos que possuem e ocupam tradicionalmente ou que tenham de outra forma utilizado ou adquirido.

2. Os povos indígenas têm o direito de possuir, utilizar, desenvolver e controlar as terras, territórios e recursos que possuem em razão da propriedade tradicional ou de outra forma tradicional de ocupação ou de utilização, assim como aqueles que de outra forma tenham adquirido. 3. Os Estados assegurarão reconhecimento e proteção jurídicos a essas terras, territórios e recursos. Tal reconhecimento respeitará adequadamente os costumes, as tradições e os regimes de posse da terra dos povos indígenas a que se refiram (NAÇÕES UNIDAS, 2008).

Em verdade, a incorporação, pelo Estado brasileiro, da Convenção 169 da OIT e da Declaração da ONU sobre os Direitos Indígenas, significou não uma ruptura ou descontinuidade, mas sim um reforço aos conceitos, princípios e regras contidos no artigo 231 da Constituição de 1988. Desta forma, há no Brasil um conjunto normativo em vigor pautado na lógica da plurietnicidade e no respeito aos modos de vida dos povos indígenas.

Situadas essas noções preliminares, cumpre agora analisar de forma mais direta o tema do presente artigo: como devemos interpretar o conceito jurídico de terra indígena vigente (positivado) no Brasil? Qual seu verdadeiro sentido: trata-se de um direito de propriedade nos moldes da propriedade privada de feição liberal, ou revela uma categoria distinta?

\footnotetext{
${ }^{5}$ Diferentemente dos tratados internacionais de direitos humanos, a Declaração da ONU sobre o Direito dos Povos Indígenas (2007) não possui “força vinculante", mas sim um caráter recomendatório, servindo como um documento de persuasão aos Estados. Não obstante, a Declaração de 2007 é um importante elemento de interpretação dos demais documentos internacionais de proteção dos direitos indígenas, de modo que não pode de forma alguma ser ignorada pelas instituições encarregadas de aplicar esses direitos.
} 
Para enfrentar essa questão, acreditamos que é necessário que o Direito se abra aos conceitos e construções teóricas de outras disciplinas, pois estamos tratando de um tema que não cabe em um sistema fechado de normas jurídicas. Vale dizer: é preciso abordar a realidade dos povos indígenas de forma interdisciplinar. No nosso caso, para tratar do conceito jurídico de terra indígena, acreditamos ser fundamental os aportes da Geografia e da Antropologia, no que tange à elaboração (e reelaboração) do conceito de território.

\section{O CONCEITO CONTEMPORÂNEO DE TERRITÓRIO NA GEOGRAFIA E NA ANTROPOLOGIA}

Ao tratar do conceito de território na Geografia, Marcelo J. L. de Souza (2008) alerta para a necessidade de despi-lo do manto de imponência com o qual se encontra, em razão da associação imediata com a ideia de Estado e de território nacional. A despeito de como tem sido tratado pela literatura científica tradicional, o autor assinala que o conceito de território "não precisa e nem deve ser reduzido a essa escala ou à associação com a figura do Estado. Territórios existem e são construídos (e desconstruídos) nas mais diversas escalas, da mais acanhada (p.ex. uma rua) à internacional” (SOUZA, 2008, p. 81).

A ideia fundamental do mencionado autor é ampliar os horizontes conceituais das Ciências Humanas, permitindo o tratamento do conceito de território nas suas diferentes escalas. Assim o território é tratado como

um campo de forças, uma teia ou rede de relações sociais que, a par de sua complexidade interna, define, ao mesmo tempo, um limite, uma alteridade: a diferença entre "nós” (o grupo, os membros da coletividade ou comunidade, os insiders) e os "outros" (o de fora, os estranhos, os outsiders). (SOUZA, 2008, p. 86).

Importante, então, não confundir o território com o espaço físico em si, pois ele reflete, na realidade, relações sociais projetadas no espaço (SOUZA, 2008). Ou, para usar uma definição clássica na Geografia brasileira, território é “o chão mais a população”, conforme ensina Milton Santos:

O território não é apenas o resultado da superposição de um conjunto de sistemas naturais e um conjunto de sistemas de coisas criadas pelo homem. O território é o chão e mais a população, isto é, uma identidade, o fato e o sentimento de pertencer àquilo que nos pertence. O território é a base do trabalho, da residência, das trocas materiais e espirituais e 
da vida, sobre os quais ele influi. Quando se fala em território, deve-se, pois, de logo entender que se está falando em território utilizado por uma dada população. Um faz o outro, à maneira da célebre frase de Churchill: primeiro fazemos nossas casas, depois elas nos fazem” (SANTOS, 2001, p. 96-97).

Salta aos olhos a semelhança entre a definição de Milton Santos com a noção de território expressa pelos povos indígenas de várias partes do mundo, baseada num texto atribuído ao Cacique Seatle, dos Estados Unidos da América: “a terra não é nossa, nós é que somos da terra” ${ }^{6}$ - frase muito utilizada pelo movimento indígena brasileiro para expressar o tipo de relacionamento que possuem com seus territórios.

Noutro giro, é preciso frisar que território e espaço físico são conceitos que não se confundem. Em sua obra "Por uma geografia do poder”, Claude Raffestin (1993) empenha-se em desfazer a confusão entre estes dois termos. Assim, destaca que o espaço é anterior ao território; o território se forma a partir do espaço, sendo o resultado de uma ação conduzida por um ator social que territorializa o espaço. O território, desta forma, é "um espaço onde se projetou um trabalho, seja energia e informação, e que, por consequência, revela relações marcadas pelo poder” (RAFFESTIN, 1993, p. 144). O espaço é aquilo que está dado, o território é aquilo que é produzido pela ação humana. ${ }^{7}$

O território como produto social, que expressa relações de poder: essa abordagem de Raffestin contribuiu, segundo Saquet e Gaglioto (2009), para uma renovação da geografia no Brasil, possibilitando uma abordagem territorial que encare as múltiplas escalas e as diversas dimensões sociais do território (economia, política e cultura). Assim, o território passa a ser enxergado como "um produto social efetivado por relações sociais, que são econômicas, políticas e culturais. Estas são as suas dimensões, que o determinam constantemente” (SAQUET e GAGLIOTO, 2009, p. 43).

Em virtude das limitações deste pequeno artigo, não será possível abordar em detalhes o conceito renovado de território no âmbito da Geografia. Vale ressaltar, no entanto, que as novas abordagens revelam-se úteis e fecundas para o estudo dos territórios de povos indígenas e comunidades tradicionais, uma vez que: a) o conceito de território deixa de ser tratado apenas

\footnotetext{
${ }^{6}$ O Grupo de Permacultura da UFPa aborda as origens e significados à Carta do Cacique Seatle, em texto disponível na página http://www.ufpa.br/permacultura/carta_cacique.htm. . Acesso em 10/07/2017.

${ }^{7}$ Em entrevista concedida a Saquet, Claude Raffestin afirma que "Não fazer a distinção entre o espaço e o território é como não fazer a diferença entre o mineral de ferro e uma ferramenta feita pelo homem. Entre os dois se intercalam numerosas etapas e numerosos processos que fazem as culturas intervirem no sentido antropológico do termo” (RAFFESTIN, 2008, p. 03).
} 
na escala do território nacional, vinculado ao Estado; b) encara-se o território como construção social, e não como simples espaço físico; e c) destaca-se a relação entre a constituição do território e a formação da identidade dos grupos humanos. Neste sentido, um diálogo entre Geografia e Antropologia parece necessário.

O próprio Souza (2008) destaca a importante contribuição da Antropologia para uma ampliação dos horizontes conceituais e teóricos acerca do território e das territorialidades. No Brasil, vários antropólogos têm utilizado o conceito de território nas suas pesquisas e estudos etnográficos sobre povos indígenas e comunidades tradicionais. Vale destacar, como exemplo, os esforços de Paul Little (2002) em construir uma antropologia da territorialidade. Alfredo Wagner Almeida (2010), por seu turno, há um bom tempo vem se dedicando a analisar os territórios de uso comum de comunidades tradicionais.

Little se propõe a analisar a diversidade sociocultural e fundiária do Brasil à luz do conceito de territórios sociais de povos tradicionais, o qual inclui diversos grupos humanos, como indígenas, quilombolas, extrativistas, pescadores artesanais, etc., que, embora possuam inúmeras diferenças entre si, apresentam características comuns em seus processos de ocupação e afirmação territorial. A análise da realidade dos povos tradicionais, em sua dimensão fundiária, permite identificar três elementos básicos: o regime de propriedade comum, o sentido de pertencimento a um lugar específico e a profundidade histórica da ocupação guardada na memória coletiva (LITTLE, 2002).

Em outras palavras: a construção histórica dos territórios dos diversos povos tradicionais do Brasil revela territorialidades similares, com muitos traços comuns. Para o mencionado autor, territorialidade é o "esforço coletivo de um grupo social para ocupar, usar, controlar e se identificar com uma parcela específica de seu ambiente biofísico, convertendo-a assim em seu território ou homeland” (LITTLE, 2002, p. 03). Deste modo, o território é encarado não como simples espaço físico, mas como produto histórico de processos sociais e políticos, isto é, das condutas de territorialidade dos grupos humanos, no caso, os povos tradicionais.

A territorialidade dos povos tradicionais não se ajusta com exatidão ao regime de propriedade vigente no Brasil, marcado pela dicotomia entre terras privadas e terras públicas. Trata-se, antes, de um regime de propriedade comum, que mescla elementos considerados como públicos (bens coletivos), mas que não são tutelados pelo Estado, e elementos tidos como privados (bens pessoais ou familiares), mas que existem fora do âmbito do mercado (LITTLE, 2002). No regime de propriedade comum da terra, o controle sobre os recursos básicos é regido 
por normas específicas instituídas para além do código legal vigente e acatadas, de maneira consensual, nos meandros das relações sociais estabelecidas entre os vários grupos familiares (ALMEIDA, 2010).

Desta forma, as terras de preto, terras de santo e terras de índio de que fala Almeida (2010) constituem verdadeiros territórios, regidos por leis consuetudinárias criadas pelos próprios povos. Em outros termos, trata-se do exercício de uma autonomia territorial, entendida como o exercício do poder de decisão legal sobre o uso dos recursos naturais, políticos, fiscais e culturais em um determinado território ou região (BARTOLOMÉ, 1995).

Assim, o conceito de território mostra-se essencial para uma adequada compreensão da realidade fundiária dos povos tradicionais no Brasil, cujas reivindicações não se voltam à redistribuição de terras, mas sim ao reconhecimento territorial, isto é, à regularização dos seus territórios. Neste sentido, é importante a distinção feita pela Geografia e pela Antropologia entre o "espaço", abstrato e genérico, e o "lugar”, concreto e habitado. O lugar é um espaço dotado de sentimento e significado, no qual certo grupo humano construiu vínculos sociais, simbólicos e rituais com o ambiente biofísico (LITTLE, 2008).

Compreender que os territórios sociais dos povos tradicionais não são simples terras, mas sim lugares dotados de relações de pertencimento cheias de significados, é um passo importante para o estabelecimento de uma relação respeitosa entre o Estado e esses povos, rompendo com um passado de violência e autoritarismo.

\section{TERRAS INDÍGENAS COMO TERRITÓRIOS: UMA CRÍTICA À MIOPIA CONCEITUAL DO JUDICIÁRIO BRASILEIRO.}

Na contramão da importante renovação teórica do conceito de território na Geografia e na Antropologia, no Direito brasileiro pouco se avançou nessa temática, sobretudo entre os agentes públicos encarregados de aplicar as leis aos casos concretos, isto é, os magistrados. Prevalece ainda, no Judiciário, uma noção de território limitada unicamente ao território nacional (Estado-nação) e aos limites territoriais dos entes federados (União, Estados e Municípios).

Os membros do Poder Judiciário costumam rejeitar enfaticamente a adoção do termo território para tratar das terras indígenas e de outras populações tradicionais:

Para a cultura constitucional, o território é um dos elementos formadores do Estado e, fisicamente, o limite de seu poder (...) 
Exatamente por isso, e especialmente nos séculos XIX e XX, as leis não admitem o nome território para indicar o espaço vital dos povos indígenas, chamando-os simplesmente de terras, como se se tratasse de terras particulares dentro do território nacional (SOUZA FILHO, 2012, p. 120-121).

Deborah Duprat (2006), por sua vez, destaca que, mesmo após a promulgação da Constituição de 1988, persiste ainda, no seio do Poder Judiciário, forte incompreensão sobre a natureza do território indígena e suas repercussões jurídicas, ensejando decisões extremamente problemáticas que acabam neutralizando os direitos territoriais previstos no artigo 231 da Carta Magna.

Para discutir a questão, faremos referência à decisão do Supremo Tribunal Federal na Petição $n^{\circ}$ 3388, que tratou da demarcação da Terra Indígena (TI) Raposa Serra do Sol (STF, 2009). A opção por esse caso deve-se ao seu caráter paradigmático no Direito brasileiro, tendo em vista que vem influenciando diversas decisões posteriores, mas também porque nele os ministros do Supremo reiteraram o entendimento que nega às terras indígenas o caráter de territórios.

Não sendo possível tratar dos pormenores do caso neste artigo, cabe ressaltar apenas que a Petição 3.388 foi uma ação popular ajuizada contra a União pelo senador da república Augusto Botelho Neto, pleiteando a declaração de nulidade dos atos administrativos que importaram na demarcação da TI Raposa Serra do Sol, no Estado de Roraima, em modelo contínuo. Além de arguir a ocorrência de vícios formais no procedimento demarcatório, o senador alegou que a demarcação comprometeria a segurança e a soberania nacionais, por se tratar de terra indígena em área de fronteira, além de prejudicar os legítimos interesses dos nãoíndios que habitam a região, a exemplo da produção agrícola (STF, 2009).

O julgamento do caso, ocorrido em 2009, representou uma vitória de pirro aos povos indígenas, pois o STF reconheceu a legalidade e legitimidade da demarcação em formato contínuo da TI Raposa Serra do Sol, porém impôs um conjunto de 19 condicionantes que limitam de forma contundente o exercício dos direitos territoriais indígenas. Estas limitações, chamadas pela Corte de "salvaguardas institucionais", foram incluídas no acórdão a partir do voto-vista do Ministro Menezes Direito (STF, 2009, pp. 359-418).

Dentre as 19 condicionantes, Yamada e Villares (2010) destacam que, em especial, as de número 5, 6, 7 e 11, representam uma regressão da política indigenista ao Século XIX. Em tais condicionantes, ficou expressamente indicada a desnecessidade de consulta aos povos indígenas em assuntos de uso e gestão de suas terras tradicionais, caso haja interesses de 
“caráter nacional”. A condicionante 5, por exemplo, autoriza a instalação de bases militares, a expansão da malha viária, a exploração de alternativas energéticas de cunho estratégico e o resguardo das riquezas de cunho estratégico a critério dos órgãos competentes, independentemente de consulta a comunidades indígenas envolvidas e à Funai (STF, 2009).

Em suma, no julgamento da Petição 3388, o STF ratificou os atos administrativos de demarcação da TI Raposa Serra do Sol, mas impôs uma série de restrições aos direitos territoriais das comunidades indígenas. Essas restrições, enunciadas como se tivessem um caráter geral, vêm sendo aplicadas pelo Judiciário em processos referentes a outras terras indígenas, o que representa um sério retrocesso na matéria.

Aprofundando o retrocesso, a Advocacia Geral da União (AGU) publicou, em 20 de julho de 2017, o Parecer $n^{\circ}$ 001/2017, que determina à administração pública federal que observe e dê efetivo cumprimento à decisão do STF no julgamento da PET nº 3388/RR, que fixou as “salvaguardas institucionais às terras indígenas”, aplicando esse entendimento a todos os processos de demarcação em andamento (AGU, 2017). Assim, as 19 condicionantes (restrições aos direitos indígenas) passam a vincular também os processos administrativos de demarcação das terras indígenas.

Voltando à questão envolvendo o conceito de território e sua aplicação à categoria terras indígenas, há que se destacar, no acórdão do STF, o item 7, que ficou assim resumido:

AS TERRAS INDÍGENAS COMO CATEGORIA JURÍDICA DISTINTA DE TERRITÓRIOS INDÍGENAS. O DESABONO CONSTITUCIONAL AOS VOCÁBULOS "POVO", "PAÍS", "TERRITÓRIO", "PÁTRIA" OU "NAÇÃO" INDÍGENA.

Somente o "território" enquanto categoria jurídico-política é que se põe como o preciso âmbito espacial de incidência de uma dada Ordem Jurídica soberana, ou autônoma. O substantivo "terras" é termo que assume compostura nitidamente sócio-cultural, e não política. A Constituição teve o cuidado de não falar em territórios indígenas, mas, tão-só, em "terras indígenas". A traduzir que os "grupos", "organizações", "populações" ou "comunidades" indígenas não constituem pessoa federada. Não formam circunscrição ou instância espacial que se orne de dimensão política. Daí não se reconhecer a qualquer das organizações sociais indígenas, ao conjunto delas, ou à sua base peculiarmente antropológica a dimensão de instância transnacional. Pelo que nenhuma das comunidades indígenas brasileiras detém estatura normativa para comparecer perante a Ordem Jurídica Internacional como "Nação", "País", "Pátria", "território nacional" ou "povo" independente. Sendo de fácil percepção que todas as vezes em que a Constituição de 1988 tratou de "nacionalidade" e dos demais vocábulos aspeados (País, Pátria, território nacional e povo) foi para se referir ao Brasil por inteiro. (STF, 2009). 
Essa redação foi elaborada a partir do voto do Relator do caso, Ministro Carlos Ayres Britto (STF, 2009, pp. 244-342). Se, por um lado, é preciso reconhecer em Ayres Britto um esforço voltado à proteção das terras indígenas, sobretudo pela ratificação do modelo contínuo de demarcação das terras, "para que se forme um perfil coletivo e se afirme a auto-suficiência econômica de toda uma comunidade usufrutuária” (STF, 2009, p. 237), por outro lado, constatase que o ministro manteve-se vinculado a uma cultura constitucional monolítica que tem dificuldades de enxergar o real significado dos territórios indígenas.

Em seu voto, Ayres Britto vincula a noção de território ao Estado, afirmando que “somente o território é que se põe como o preciso âmbito espacial de incidência de uma dada Ordem Jurídica soberana, ou, então, autônoma” (STF, 2009, p. 277). Afirma também que o substantivo “terras”, referido às etnias indígenas, assume compostura nitidamente sociocultural, não política; de modo que os grupos indígenas não constituem pessoa federada (STF, 2009). Sobre este ponto, conclui o ministro:

Em tema de índios, não há espaço constitucional para se falar em polis, território, poder político, personalidade geográfica (...) O que de pronto nos leva a, pessoalmente, estranhar o fato de agentes públicos brasileiros aderirem, formalmente, aos termos da recente "Declaração das Nações Unidas Sobre os Direitos dos Povos Indígenas”, porquanto são termos afirmativos de um suposto direito à autodeterminação política, a ser "exercido em conformidade com o direito internacional”. Declaração, essa, de que os índios nem sequer precisam para ver a sua dignidade individual e coletiva juridicamente positivada, pois o nosso Magno Texto Federal os protege por um modo tão próprio quanto na medida certa (STF, 2009, p. 280-281).

Neste trecho, salta aos olhos o provincianismo constitucional do Ministro Ayres Brito (que é compartilhado pelo STF em seu conjunto, assim como pela maioria do Judiciário brasileiro), isto é, a insistência em desconsiderar ou minimizar a importância das normas internacionais de direitos humanos, num apego apaixonado pela legislação nacional. De igual forma, a posição de Ayres Brito revela uma cultura jurídica estatista, na qual o conceito de território continua coberto com seu manto de imponência (SOUZA, 2008), o que impede a visualização das suas diversas escalas, no caso, a escala dos territórios sociais dos povos tradicionais (LITTLE, 2002).

A despeito da preocupação do ministro Ayres Britto, reconhecer que as terras indígenas equivalem a territórios não importa em atribuir a elas o status de entes federados. 
Aliás, não é isso que reivindicam os povos indígenas no Brasil, mas sim o reconhecimento, respeito e proteção, pelo Estado, dos seus territórios, com garantia de autonomia territorial.

A decisão proferida nos autos da Petição 3388 confirma o diagnóstico feito por Souza Filho (2012) sobre a forma como o Judiciário encara os povos indígenas: causa repulsa às autoridades estatais e aos juristas brasileiros chamar as terras indígenas de território, tanto quanto chamá-los de povos, pois “estas duas palavras, povo e território, somadas à soberania, tem o som de tambores belicosos, de guerra de libertação, de insurreição e independência e, por isso, sofrem imediata e irracional repulsa de todos os setores que se dizem nacionalistas” (SOUZA FILHO, 2012, p. 121).

O referido autor assinala que, embora a Constituição de 1988 não fale em territórios indígenas, mas sim em terras indígenas, “o conceito de território está escondido atrás das normas constitucionais que regem a matéria e, especialmente, atrás da coerência sistêmica da Constituição e de todo o ordenamento jurídico” (SOUZA FILHO, 2012, p. 121). Isso porque o tratamento jurídico dado às terras indígenas, no artigo 231 da Constituição, não se enquadra na dicotomia clássica entre terras públicas (do Estado) e terras privadas (de apropriação individual, particular); pelo contrário, reconheceu-se aos povos indígenas um poder de gestão sobre suas terras, isto é, a jurisdição sobre um espaço geográfico.

Ao afirmar que (a) as terras tradicionalmente ocupadas pelos índios são aquelas utilizadas para habitação, atividades produtivas, bem como as imprescindíveis à preservação dos recursos ambientais e à sua reprodução física e cultural, segundo seus usos, costumes e tradições (artigo 231, § $1^{\circ}$ ), e (b) que as riquezas presentes nas terras indígenas estão reservadas ao usufruto exclusivo dos índios (artigo 231, § $2^{\circ}$ ), a Constituição reconheceu aos povos indígenas o direito ao território, embora de forma envergonhada.

A previsão constitucional do usufruto exclusivo proíbe a apropriação privada dos recursos naturais das terras indígenas pelos não-índios. Há, portanto, a definição de um limite entre o "nós” e os “outros” (SOUZA, 2008). E, do ponto de vista interno, a utilização dos recursos naturais presentes nas terras indígenas será feita conforme os usos, costumes e tradições dos povos indígenas, isto é, conforme o seu Direito (jurisdição indígena).

É vedado, portanto, o exercício do direito brasileiro de propriedade dentro das terras indígenas, mas, ao contrário, são cogentes as normas do direito consuetudinário indígena. Dentro deste raciocínio, estamos falando de território, embora sem soberania e com pouca autonomia (SOUZA FILHO, 2012, p. 123). 
Por outro lado, embora a Constituição não utilize expressamente o vocábulo território para se referir às terras indígenas, é preciso colocar essa questão em foco à luz do bloco normativo sobre os direitos indígenas, que envolve, além da Constituição, a Convenção 169 da OIT. Ao contrário do provincianismo constitucional que domina a cultura jurídica nacional, acreditamos que o apelo aos tratados internacionais sobre direitos humanos são instrumentos fundamentais na proteção dos povos indígenas ${ }^{8}$.

Nesse sentido, convém atentar que a Convenção nº 169 da OIT menciona por três vezes o termo "território" para se referir às terras indígenas: uma no seu artigo $7^{\circ}$, item 4 , e outras duas no artigo 13, itens 1 e 2. Mais que isso: a própria Convenção 169 afirma que terra indígena é uma categoria que abrange o conceito de território, conforme enunciado do item 2 do artigo 13:

\begin{abstract}
Artigo 13
1. Ao aplicarem as disposições desta parte da Convenção, os governos deverão respeitar a importância especial que para as culturas e valores espirituais dos povos interessados possui a sua relação com as terras ou territórios, ou com ambos, segundo os casos, que eles ocupam ou utilizam de alguma maneira e, particularmente, os aspectos coletivos dessa relação.

2. A utilização do termo "terras" nos Artigos 15 e 16 deverá incluir o conceito de territórios, o que abrange a totalidade do habitat das regiões que os povos interessados ocupam ou utilizam de alguma outra forma (grifo nosso) (BRASIL, 2004).
\end{abstract}

Na mesma toada, a Declaração da ONU sobre os Povos Indígenas, apontada pelo ministro Ayres Brito como um documento inócuo para a proteção dos direitos dos índios (opinião que não é compartilhada pelas organizações representativas dos povos indígenas!), utiliza por dezenove vezes o termo "território” para se referir às terras indígenas. No artigo 25 da Declaração, afirma-se que os povos indígenas têm o direito de manter e de fortalecer sua própria relação espiritual com as terras, territórios, águas, mares costeiros e outros recursos que tradicionalmente possuam ou ocupem e utilizem, e de assumir as responsabilidades que a esse respeito incorrem em relação às gerações futuras (NAÇÕES UNIDAS, 2008).

Mas é no artigo 26 que melhor aparece a definição de terra indígena como território dos povos indígenas, marcado por uma ocupação tradicional e regulado pelos costumes e tradições dos povos:

\footnotetext{
${ }^{8} \mathrm{O}$ art. $7^{\circ}$, item 4 da Convenção 169 dispõe que "Os governos deverão adotar medidas em cooperação com os povos interessados para proteger e preservar o meio ambiente dos territórios que eles habitam” (BRASIL, 2004).
} 


\section{Artigo 26}

1. Os povos indígenas têm direito às terras, territórios e recursos que possuem e ocupam tradicionalmente ou que tenham de outra forma utilizado ou adquirido.

2. Os povos indígenas têm o direito de possuir, utilizar, desenvolver e controlar as terras, territórios e recursos que possuem em razão da propriedade tradicional ou de outra forma tradicional de ocupação ou de utilização, assim como aqueles que de outra forma tenham adquirido. 3. Os Estados assegurarão reconhecimento e proteção jurídicos a essas terras, territórios e recursos. Tal reconhecimento respeitará adequadamente os costumes, as tradições e os regimes de posse da terra dos povos indígenas a que se refiram (NAÇÕES UNIDAS, 2008).

Deste modo, podemos concluir que, se a Constituição reconhece implicitamente que as terras indígenas são territórios, conforme lição de Souza Filho (2012), a Convenção 169 da OIT (tratado internacional, com força vinculante) e a Declaração das Nações Unidas sobre os Direitos do Povos Indígenas (documento internacional de caráter recomendatório, com caráter persuasivo diante dos Estados) reconhecem essa correlação de conceitos de forma expressa.

Assim, por força do próprio Direito vigente no Brasil, não há como negar a correlação entre a categoria jurídica terras indígenas e o conceito contemporâneo de território na Geografia e na Antropologia. Longe de ser um debate meramente acadêmico acerca da nomenclatura correta, a questão colocada neste artigo tem implicações práticas cruciais para os direitos territoriais dos povos indígenas. A nosso ver, a posição do STF de que as terras indígenas não devem ser encaradas como territórios guarda sintonia com as limitações à autonomia dos povos indígenas impostas pelas 19 condicionantes do caso Raposa Serra do Sol.

Ao dizer que não se trata de território, mas de terras, o Judiciário sinaliza para uma redução do poder que têm os povos indígenas sobre seu espaço vital. Por isso, ao julgar o caso paradigmático da Terra Indígena Raposa Serra do Sol, o STF autorizou a execução de iniciativas de “interesse nacional” dentro de terras indígenas, mesmo sem consulta aos povos afetados, como a instalação de bases militares, a expansão da malha viária ou a exploração de alternativas energéticas (STF, 2009). Um visível retrocesso no campo das políticas indigenistas, que desfigura o bloco normativo composto pela Constituição de 1988 e pela Convenção 169 da OIT.

\section{CONSIDERAÇÕES FINAIS}


Com base na pesquisa empreendida na elaboração deste artigo, podemos concluir que a Constituição de 1988 consagrou importantes avanços na proteção dos direitos territoriais indígenas, os quais foram reforçados com a incorporação ao direito brasileiro da Convenção 169 da Organização Internacional do Trabalho e da Declaração das Nações Unidas sobre os Povos Indígenas. Todavia, persiste entre os membros do Poder Judiciário uma séria incompreensão sobre a natureza de tais direitos, o que acarreta problemas na sua implementação.

Essa incompreensão foi focalizada neste artigo à luz do conceito de terras indígenas e da recusa do Poder Judiciário em reconhecer que se trata de categoria correlata ao conceito de território. Some-se a isso o provincianismo constitucional dos membros do Judiciário, que os faz renegar a importância dos documentos internacionais sobre direitos humanos, particularmente sobre os direitos humanos dos povos indígenas.

Essa interpretação limitada e restritiva dos direitos territoriais redunda em decisões judiciais que limitam a autonomia dos povos indígenas na gestão e utilização dos seus espaços vitais, como se viu no julgamento da TI Raposa Serra do Sol, no qual o STF impôs 19 condicionantes (restrições de direitos) à demarcação das terras indígenas. Tais condicionantes sendo aplicadas para outras terras indígenas, por conta de um Parecer Vinculante da Advocacia Geral da União aprovado em 2017.

Este artigo representa, portanto, um esforço modesto de contestação à cultura estatista que domina o Poder Judiciário no que tange aos povos indígenas. A consolidação do Estado brasileiro como um Estado pluriétnico e multicultural, intentada pelo legislador constituinte de 1988, exige que se garanta aos povos indígenas o direito à autonomia e autogestão de seus territórios; afinal, trata-se de um direito originário, anterior ao próprio Estado, cuja garantia é condição da reprodução física e cultural dos povos indígenas.

\section{REFERÊNCIAS}

AGU - Advocacia Geral da União. Parecer nº 001/2017/GAB/CGU/AGU. Diário Oficial da União, 20 de julho de 2017.

AFONSO DA SILVA, José. Curso de Direito Constitucional Positivo. 30a ed. São Paulo, Malheiros, 2008. 
ALMEIDA, Alfredo W. B. Terras de preto, terras de santo, terras de índio: uso comum e conflito. In: BRASIL. Ministério do Desenvolvimento Agrário. "Brasil rural em debate: coletânea de artigos”. Brasília: CONDRAF/MDA, 2010. pp. 104-136.

BRASIL. Constituição da República Federativa do Brasil, de 5 de outubro de 1988. Disponível em: http://www.planalto.gov.br/ccivil_03/Constituicao/Constituicao.htm. Acesso em 20/01/2017.

. Decreto $n^{\circ}$ 5.051, de 19 de abril de 2004, que promulga a Convenção 169 da OIT. Disponível em: http://www.planalto.gov.br/ccivil_03/_ato2004-2006/2004/decreto/d5051.htm. Acesso em 12/07/2017.

Lei $n^{\circ}$ 6.001, de 19 de dezembro de 1973 (Estatuto do Índio). Disponível em:

Acesso em: 04/04/2018.

Constituição da República dos Estados Unidos do Brasil, de 16 de julho de 1934. Disponível em: http://www.planalto.gov.br/ccivil_03/constituicao/constituicao34.htm. Acesso em 12/07/2017.

Lei $n^{\circ}$ 601, de 18 de setembro de 1850. Dispõe sobre as terras devolutas do Império. Disponível em: http://www.planalto.gov.br/ccivil_03/Leis/L0601-1850.htm. Acesso em 12/07/2017.

CARNEIRO DA CUNHA (org.) História dos índios no Brasil. São Paulo: Companhia das Letras - Secretaria Municipal de Cultura - FAPESP, 1992.

CAVALCANTE, Thiago Leandro Vieira. "Terra indígena": aspectos históricos da construção e aplicação de um conceito jurídico. História [online], São Paulo, 2016, vol.35, e75. Disponível em: http://dx.doi.org/10.1590/1980-436920160000000075. Acesso em 06/07/2017.

DUPRAT, Deborah. O papel do judiciário. In: “Povos indígenas no Brasil: 2001-2005”. São Paulo, ISA, 2006. pp. 172-175.

LITTLE, Paul E. Territórios sociais e povos tradicionais no Brasil: por uma antropologia da territorialidade. Série Antropologia, $\mathrm{n}^{\circ}$ 322. Brasília-DF, 2002. Disponível em: http://www.direito.mppr.mp.br/arquivos/File/PaulLittle_1.pdf. Acesso em 03/07/2017.

NAÇÕES UNIDAS. Declaração das Nações Unidas sobre os Direitos dos Povos Indígenas. Centro de Informações das Nações Unidas, Rio de Janeiro, 2008.

RAFFESTIN, Claude. Por uma geografia do poder. Tradução: Maria Cecília França. São Paulo, Editora Ática, 1993.

Entrevista. Revista Formação, n. 15, volume 1, 2008. Disponível em: http://revista.fct.unesp.br/index.php/formacao/article/view/686/713. pp. 01-05. Acesso em 11/07/2017. 
SANTOS, Milton. Por uma outra globalização - do pensamento único à consciência universal. $6^{\text {a }}$ ed. Rio de Janeiro, Editora Record, 2001.

SAQUET, Marcos Aurélio; GAGLIOTTO, Ana Rúbia. Abordagens das dimensões sociais do território. In: ALMEIDA, M.G.; CRUZ, B.N (org.). "Território e cultura: inclusão e exclusão nas dinâmicas socioespaciais”. Goiânia, 2009.

SOUZA, Marcelo José Lopes de. O território: sobre espaço e poder, autonomia e desenvolvimento. In: CASTRO, Iná Elias, et. al. (org.). “Geografia: conceitos e temas”. $11^{\text {a }}$ Ed. Rio de Janeiro, Bertrand Brasil, 2008. pp. 77-116

SOUZA FILHO, Carlos Frederico Marés. O renascer dos povos indígenas para o Direito. Curitiba, Juruá Editora, 2012.

STF - SUPREMO TRIBUNAL FEDERAL. Petição 3388, Relator: Ministro Carlos Britto. Tribunal Pleno. Julgado em 19/03/2009. Publicação: 25/09/2009.

YAMADA, Erica Magami; VILLARES, Luiz Fernando. Julgamento da Terra Indígena Raposa Serra do Sol: todo dia era dia de índio. Revista Direito GV, 2010, vol.6, pp. 143-158. 